\title{
Influence of metal bar lever-arm on screws detorque for dental prosthesis implant supported
}

\author{
Influência do cantilever no destorque de parafusos de barras metálicas \\ utilizadas em próteses do tipo protocolo de Brannemark
}

\author{
Wilson MATSUMOTOa* (D), Ana Paula MACEDO ${ }^{a}$ (i), Rossana Pereira de ALMEIDA ${ }^{a}$ (D), \\ Anselmo Agostinho SIMIONATOa (D), Takami Hirono HOTTA ${ }^{a}$ (1) \\ aUSP - Universidade de São Paulo, Faculdade de Odontologia de Ribeirão Preto, Departamento de Materiais \\ Odontológicos e Prótese, Ribeirão Preto, SP, Brasil
}

\begin{abstract}
How to cite: Matsumoto W, Macedo AP, Almeida RP, Simionato AA, Hotta TH. Influence of metal bar lever-arm on screws detorque for dental prosthesis implant supported. Rev Odontol UNESP. 2020;49:e20200047. https://doi.org/10.1590/18072577.04720
\end{abstract}

\begin{abstract}
Resumo
Introdução: 0 comprimento do cantilever da infraestrutura de prótese implanto-suportada tem sido considerado um importante fator de transferência de força de oclusão para o implante dentário. Objetivo: Esse trabalho avaliou a influência das diferentes extensões do cantilever da prótese sobre implantes tipo protocolo de Branemark submetidas à termociclagem mecânica pela avaliação dos afrouxamentos dos parafusos de fixação. Material e método: Os grupos G10 (n=5), G15 (n=5) e G20 (n=5) foram formados de acordo com a distância, em milímetros, entre o local de aplicação de força no cantilever e o centro do último implante. Todas as barras $(\mathrm{n}=15)$ foram submetidas a carga vertical cíclica de $120 \mathrm{~N}$ em uma máquina de simulação de mastigação (MSM-Elquip, São Carlos/SP, Brasil), em condições de temperatura e umidade controladas. Foram realizados 250 mil ciclos mecânicos com frequência de $2 \mathrm{~Hz}$ que simulou uma atividade mastigatória correspondente a 3 meses. Para comparar os dados obtidos quanto à soltura dos parafusos da barra, a posição dos implantes e os locais de aplicação de carga, foi realizada a análise de variância com dois fatores e o teste de Tukey. Resultado: A análise estatística mostrou que o grupo G10 apresentou maior perda de torque, diferente estatisticamente de G15 (p=0,001) e G20 (p=0,002) e que não houve diferença significante entre os grupos G15 e G20. Conclusão: Pode-se concluir que todos os parafusos apresentaram perda de torque após o ensaio simulando uma atividade mastigatória de 3 meses, sugerindo a necessidade de avaliação clínica periódica afim de prevenir fracasso no tratamento.
\end{abstract}

Descritores: Implantes dentários; prótese dentária cirúrgica; dentadura fixada por implante; conexão implante dentário-pivô.

\begin{abstract}
Introduction: The cantilever length of implant-supported fixed prosthesis metal structure has been considered an important factor to transfer occlusion forces to the dental implant. Objective: This study evaluated the influence of different extensions of cantilevers of Branemark protocol implant prosthesis when submitted to mechanical thermocycling by screw loosening evaluation. Material and method: The groups G10 ( $=5), \mathrm{G} 15(\mathrm{n}=5)$ and G20 ( $=5$ ) were formed according to the distance in millimeters between the force application site in the cantilever and the center of the last implant. All metal structures ( $\mathrm{n}=15$ ) were submitted to a $120 \mathrm{~N}$ cyclic vertical load in a chewing simulation machine (MSM-Elquip, São Carlos-SP, Brazil) under controlled temperature and moisture conditions. Two hundred and fifty thousand mechanical cycles were performed with a frequency of $2 \mathrm{~Hz}$ that simulates a masticatory activity similar to 3 months. To compare the data obtained regarding the loosening of the metal structure screws, implant position and sites of load application, the analysis of variance with two factors and the Tukey test were performed. Result: Statistical analysis showed that the G10 group presented greater torque loss, statistically different from G15 ( $p=0.001)$ and G20 ( $\mathrm{p}=0.002)$, and there was no significant difference between groups G15 and G20. Conclusion: It can be concluded from the results that all the screws presented torque loss after simulation of 3 month masticatory activity, suggesting the need for periodical evaluation to prevent failures in the treatment.
\end{abstract}

Descriptors: Dental implants; dental prosthesis; denture, implant-supported; dental implant-abutment design. 


\section{INTRODUCTION}

The success of an oral rehabilitation is related to the use of adequate techniques and materials that allow a fixed prosthesis supported by teeth or implants presenting a uniform distribution of forces and an exact and passive adaptation ${ }^{1}$. With the development in the dental area, more options of techniques and materials are being made available to dentists, in addition to conventional techniques. The implant does not have periodontal ligament, therefore, it presents no adaptive capacity as the tooth, consequently, in the implant prosthesis, the passive fitting of the framework is an important requirement for the success of the dental treatment ${ }^{2}$.

The implant prosthesis type Branemark protocol is universally accepted for the rehabilitation of complete edentulous 3,4 . This is a type of prosthesis that uses a metal framework with distal extension, usually bilaterally, with a variable extension, called cantilever. The lever-arm produced by the cantilever is considered one of the causes of mechanical problems in the prosthesis, implant and bone tissue. One of these mechanical problems is the loosening of the prosthesis fixation screws ${ }^{5,6}$, that can be associated with the mismatch of prosthetic components 7,8 . The screw retention loss occurs when the masticatory loading causes sliding of the screw threads and vibrations, resulting in detorque and damages to the screwed bolt ${ }^{9}$. The load resulting from the function also is transmitted to implant-abutment interface and crestal bone, directly affected by the biomechanical behavior of the components ${ }^{6}$. As a result, rotation and deflection movements derived from mismatch can cause bone resorption over time ${ }^{8}$.

Screw loosening is a technical problem most encountered in extenally connected abutments 6 . Such complication relates to screw-closing torque and an non-accurately fitted framework 5,10 , showing an incidence of $6,7 \%$ in 5 years 5 , when used in fixed partial dentures. In a previous study, after a $30 \mathrm{Ncm}$ torque, the detorque observed was $16.24 \mathrm{Ncm}$ for calcinable abutments and $13.91 \mathrm{Ncm}$ for overcasted abutments after applying a cyclic load of $130 \mathrm{~N}$ and $2 \mathrm{~Hz}$, presenting similar behavior with clinical use ${ }^{9}$. Loosening or detorque of the screw can decrease the clamping forces, causing misfits, which can lead to biologic and mechanical complications ${ }^{11}$. A perfect fit is not achieved by multiunit implant-supported dentures ${ }^{11}$, when associated with the lever-arm originating from the cantilever it can lead to undesirable forces in the functioning of the prosthesis. Optimizing stress distribution is the goal of rehabilitation with dental implants. Strain gauge studies to understand the stress distribution in abutments and frameworks were performed ${ }^{10,12,13}$, but the specific effect of cantilever on screw loosening still needs further studies. The objective of this study was to evaluate the influence of treedifferent extensions of the cantilever framework for implant prosthesis type Branemark protocol, when submitted to mechanical thermocycling. The hypothesis tested was that longer length of the cantilever leads to higher screw detorque.

\section{MATERIAL AND METHOD}

The master model was constructed from a transparent acrylic resin lower jaw model (Nacional Ossos, Jau, SP, Brazil) with four replicas of mini conical abutment with $4.1 \mathrm{~mm}$ in diameter (Conexão, São Paulo, Brazil), simulating a fixed prosthesis Branemark-type protocol with 4 implants. The sample size (number of implants for each group) was determined by means of a previous study ${ }^{11}$. The difference between mean detorque in passive dentures titanium implants was 1.0 (95\% of CI, power of $80 \%$, variance of 0.7 and 0.8 ). The sample size analysis pointed the need for 8 implant replicas for each group, 20 were used.

To transfer the position of the mini conical abutment replicas, four miniconical square transfers (Conexão, São Paulo, Brazil) were adapted to the replicas in the master model, joined with dental floss and acrylic resin (Duralay - Reliance Co, Worth Illinois - USA). After 
polymerization, the resin-dental floss set were cut between transfers with a \#170L carbide bur to compensate the stress of acrylic resin polymerization shrinkage. The sectioned parts were then rejoined with acrylic resin (Duralay, Reliance, Worth, Illinois, USA). The impressions were made with condensation silicone (Zetaplus System-Zhermack), and the light material was deposited directly on the ferulized transfers and the heavy material in the impression tray. After polimerization of the impression material, the impressions were removed from the master model with the transfers grabbing onto the impression material. For the preparation of the gypsum cast, replicas were adapted in the transfers and the gypsum was poured into the impression, the process was repeated until obtaining 3 models.

Miniconical plastic cylinders (Conexão, São Paulo, Brazil) were adapted to the gypsum cast. Acrylic resin bars (Duralay, Reliance Co - USA) measuring $5 \mathrm{~mm}$ high and $4 \mathrm{~mm}$ wide, were attached to the plastic cylinders with wax (Renfert, Germany). A thin layer of wax was applied throughout the set, in order to obtain a standardization of the patterns. To obtain the metal bar in $\mathrm{Co}-\mathrm{Cr}$, the one-piece patterns were included in metal-cast investment and after casting were kept on the bench at room temperature for 1 hour to avoid dimensional changes in the metal structures. Then, the specimens passed through the process of disintegration, finishing and blasting with aluminum oxide of granulation 100 micron and pressure of $60 \mathrm{lbs} / \mathrm{in}^{2}$, finalizing the process of obtaining the metal structure $(n=3)$.

For the load tests, epoxy resin models were made $(n=15)$. Each metal bar was adapted and fixed in the master model with the help of a long screw (Conexão, São Paulo, Brazil) (Figure 1) and transfer impression was performed with Express addition silicone (3M-ESPE). In the impression, four miniconical replicas (Conexão, São Paulo, Brazil) were adapted and epoxy resin (F160, Axson, Brazil) was poured. For each bar, 5 models were obtained, forming the experimental groups called Group G10, Group G15 and Group G20, according to the extension of the cantilever $(10,15$ or $20 \mathrm{~mm})$.

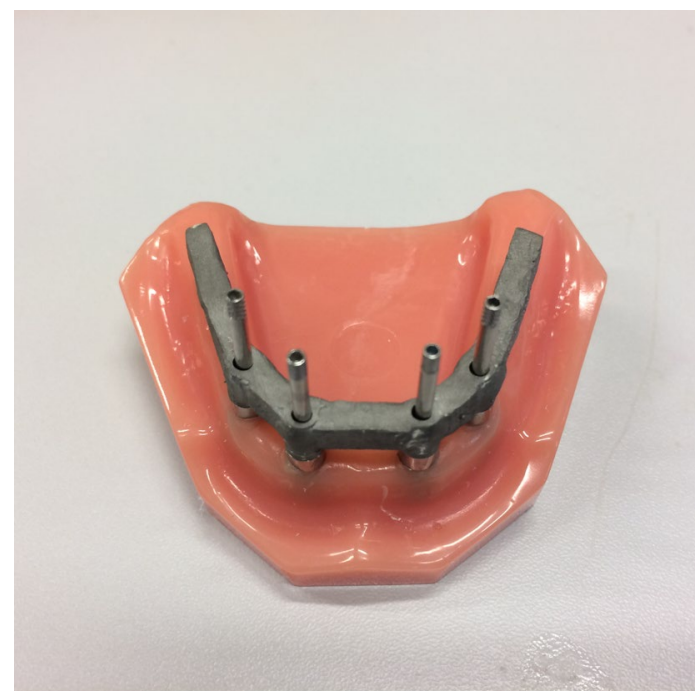

Figure 1. Metal infrastructure adapted on the master model.

Each metal structure was fitted onto its epoxy resin cast and screwed using a digital torque wrench (TQ 680 - Instruterm Instrumentos de Medição Ltda - São Paulo, SP, Brazil), with 10 $\mathrm{Ncm}$, following the sequence 2-4-3-13 (Figure 2). After 10 minutes of the preload, the screws were again torqued, as recommended by the manufacturer for gold and titanium screws ${ }^{11}$. A single examiner was calibrated to perform the torque and detorque of the screws, standardizing the speed of the procedures. 


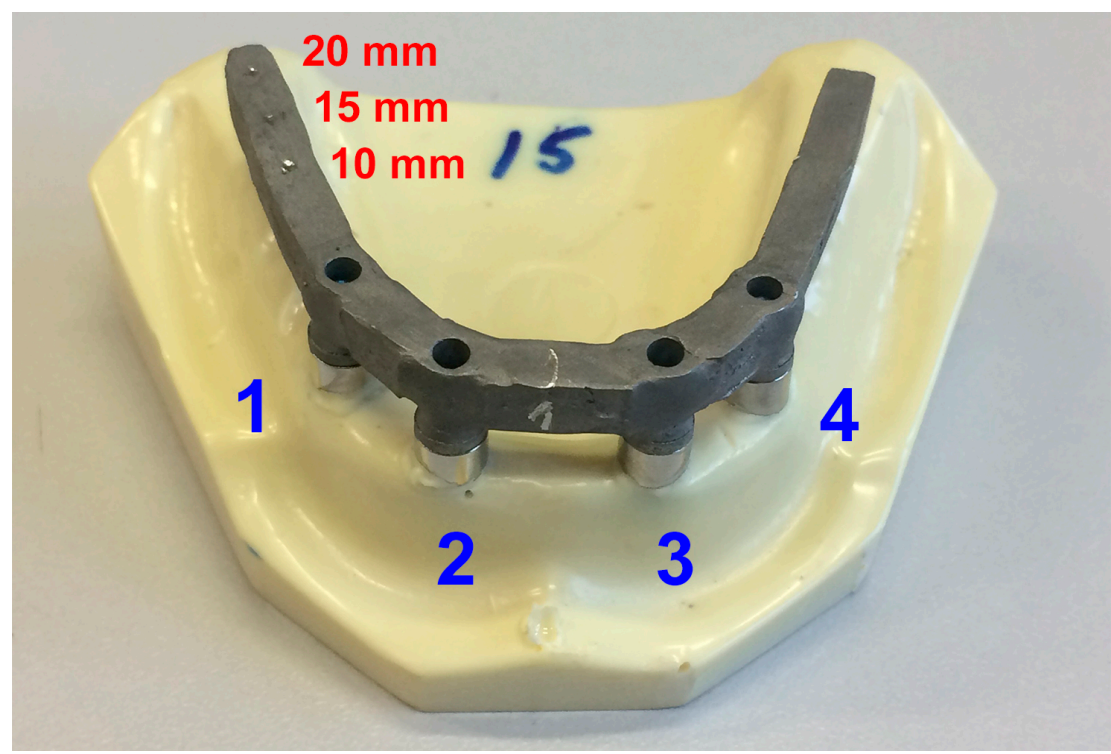

Figure 2. Epoxy Resin cast and metal infrastructure. Blue numbers indicate the position of the implants; Red numbers indicate the load application distance (markings on the framework were made with a milling cutter).

Three models of epoxy resin with 3 metal structure with 10, 15 and $20 \mathrm{~mm}$ cantilever, respectively, were positioned in the mastication simulation machine (MSM-Elquip Equipamentos para Pesquisa Odontológica, São Carlos/SP, Brazil). In each metal structure, a $120 \mathrm{~N}$ cyclic vertical load was applied at a distance of 10,15 or $20 \mathrm{~mm}$ from the center of the last implant on the right side of the bar. During the course of the test, the models with the respective metal structure were kept in distilled water, with temperature variation of 5-55 degrees Celsius. Two hundred and fifty thousand mechanical cycles were performed with a frequency of $2 \mathrm{~Hz}$ that simulates a masticatory activity corresponding to 3 months ${ }^{11,14}$. (Figure 3).

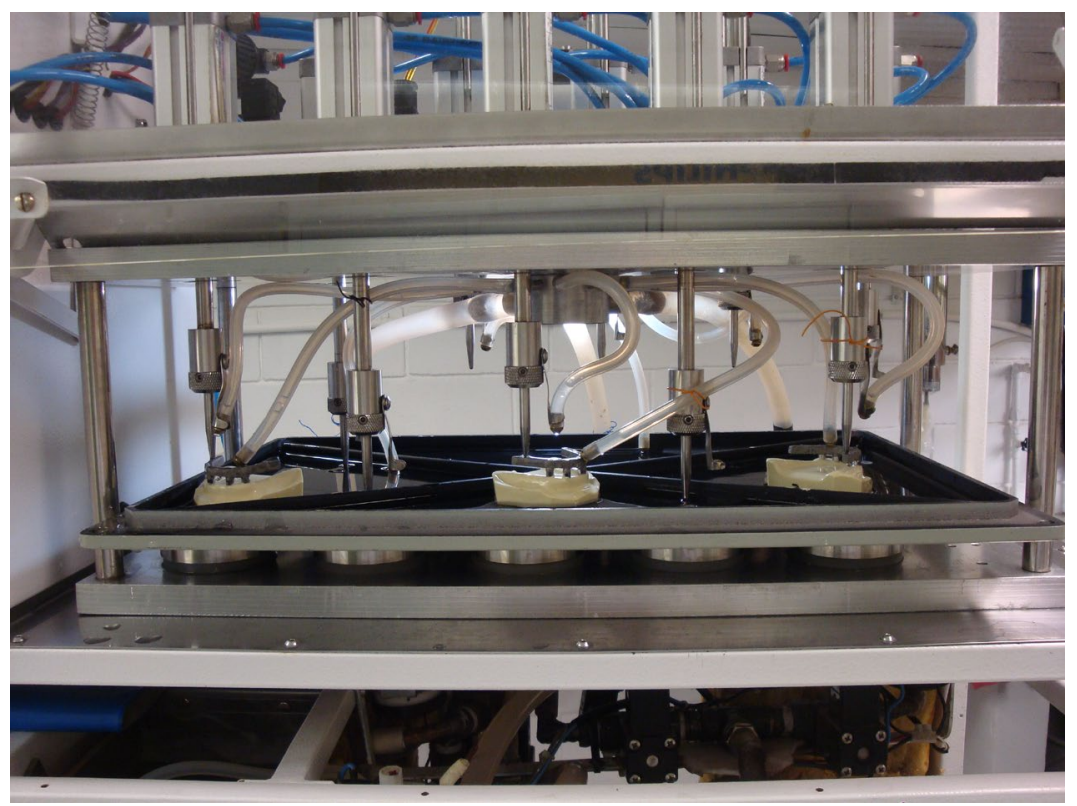

Figure 3. Metal infrasctrutures and the epoxy resin casts on the test machine.

The assay was repeated, with one element from each group, until all models/metal structure were thermocycled. 
Immediately after the thermocycling test, with a digital torque wrench (TQ 680 - Instruterm Instrumentos de Medição Ltda - São Paulo, SP, Brazil) inserted in the screws, in the sequence 2$4-1-3$, the value of the detorque of each screw from the metal structure were obtained.

\section{RESULT}

The results showed that screws, in all groups, presented torque loss after mechanical thermocycling, simulating 3 month-masticatory activities.

Two-way ANOVA and Tukey post-test showed no significant difference between groups $(\mathrm{p}<0.001)$ and between implants $(\mathrm{p}=0.038)$ and the interaction between implant-group showed no significance.

Table 1 shows the mean and standard deviation of torque loss between groups. The group G10 showed greater loss torque and statistically different from groups G15 (p=0.001) and group G20 ( $p=0.002$ ). It was observed no difference between G15 and G20.

Table 1. Mean (standard deviation) of torque loss between groups and statistical comparisons

\begin{tabular}{cc}
\hline Group & Torque Loss \\
\hline G10 & $4.50(0.74)^{\mathrm{a}}$ \\
\hline G15 & $3.47(1.06)^{\mathrm{b}}$ \\
\hline $\mathrm{G} 20$ & $3.54(0.87)^{\mathrm{b}}$ \\
\hline $\mathrm{p}$ & $<0.001$ \\
\hline $\mathrm{a}, \mathrm{b}$ Same letters indicate statistical similarity &
\end{tabular}

a,bSame letters indicate statistical similarity.

\section{DISCUSSION}

The implant prosthesis type Branemark protocol is universally accepted for the rehabilitation of complete edentulous 3,4 . This is a type of prosthesis that uses a distal extension, usually bilaterally, with a variable extension called cantilever.

The lever arm is considered one of the causes of mechanical problems in the prosthesis, implants and bone tissue, when forces are applied to the cantilever. One of these problems is the loosening of the prosthesis fixation screws ${ }^{5,6}$. Some studies reported that $49 \%$ of the screws of implant prosthesis type Branemark protocol were lost in the first two evaluation sessions ${ }^{10}$. The length of the lever-arm increases tensile, compressive and shear forces, resulting in greater stress on the prosthesis. To reduce the effect of these factors, a large resistance arm is desirable, obtained with placement of anteriorly implants ${ }^{15}$. Therefore, this high percentage indicates the need to think about clinical actions and the time interval for prosthetic reassessment. This work had the objective of verifying the behavior of the screws of fixation of metal structures after mechanical thermocycling simulating a masticatory activity corresponding to 3 months. This was performed by means of analysis of the torque and detorque measurements of the prosthesis screws.

The torque loss represents, in this study, the difference between the final torque and the torque required to fully loosen the metal structure screws. All groups showed results in which the mean value of detorque was lower than the initial tightening, i.e. the screws were loosened during the experiment. This result is in agreement with other studies ${ }^{11}$.

It was observed that the G10 group presented greater torque loss than the G15 group ( $p=0.001$ ) and G20 group ( $\mathrm{p}=0.002)$, contradicting the study hypothesis. There was no difference between the G15 and G20 groups ( $p=0.957$ ), that is, the torque loss values were similar. In the literature, there are studies about cantilever with different extensions submitted to several 
research protocols ${ }^{16}$. The analysis of the torque loss related to the cantilever extension may be a parameter to be considered in the planning of an implant prosthesis, especially because patients, frequently, request a prosthesis with a similar length to the natural dentition.

In the present study, the physical response to the applied occlusal load was the loosening of the screw that retains the metal structure to the prosthetic component and this condition occurred in all experimental groups, regardless of the cantilever extension. These results are, clinically, very important, because the screw loosening may lead to loss of the sealing and allow bacterial growth ${ }^{17}$, as well as more serious complications ${ }^{18}$ such as granulation tissue growth between the implant and the abutment, possibly resulting in fistula, biofilm deposition between the abutment and the prosthesis ${ }^{19}$ and fracture of prosthetic components or bone loss around the implant ${ }^{11}$.

Screw loosening is a frequent complication of implant prosthesis ${ }^{5,6}$. The process of screw loosening occurs in two stages. Initially, mastication or other external forces cause sliding of the screw threads, relieving the preload of the screw. At this stage, the higher the preload, greater the resistance to screw loosening. The second stage is reached by a gradual reduction of the preload below a critical level, that is able to cause damage to the screwed bolt 9 .

Studies evaluating the preload loss on prosthetic screws, over time, found a reduction of $24.9 \%$ after 15 hours, and of these, $40.2 \%$ loosened after 10 seconds of tightening ${ }^{20}$. Then, in this study, before each metal strucuture was submitted to the test, all the screws received torque of $10 \mathrm{Ncm}$ and, after 10 minutes, were re-tightened with the torque wrench to confirm and reach $10 \mathrm{Ncm}$. This was a strategy used to maintain the torque, as close as possible to $10 \mathrm{Ncm}$ at the beginning of the tests, as proposed in the studies of Breeding et al. ${ }^{21}$ and Dixon et al. ${ }^{8}$, and as a clinical practice by Siamos et al. ${ }^{14}$.

The torque loss presented in the shortest cantilever extension group (G10) presented higher than that of the other groups, and had a different finding in relation to other studies that reported a higher risk of complications in a longer cantilever ${ }^{5,6}$ or even no related difference ${ }^{17}$. More studies are necessary to verify if the higher torque loss in this group could be related to the minimization of the problems in the prosthesis or in the abutment/implant closest to the load application site.

In this study, it was possible to note that the metal structure of G20 presented, visually during the test, more deflection than the G10. This increased deflection could cause lower load on the screw, similar to the work of Jacques et al. ${ }^{13}$ with the Ag-Pd structure. The group G10 presented greater loosening of the screws. This result could be because the smaller lever arm produces less bar deflection and consequently greater overload on metal structure screws.

The loosening of screws with several implants may indicate overloading in another until it also loosens ${ }^{7}$ and so on. This can happen successively to the release of all or a fracture of some, when the professional or the patient notices what happened, but possibly not every fractured screw indicates of being overloading.

In the test, the metal structure was subjected to the load of $120 \mathrm{~N}$, on the right side, in a site located 10, 15 and $20 \mathrm{~mm}$ from the last implant. Screw number 4 presented the greatest torque loss, probably due to its position at the extreme contralateral side to the force application, contradicting Jemt ${ }^{22}$ who reported not having found a high incidence of forces on the contralateral side.

Several studies also presented different results regarding the position of the implant, reporting higher stress in the region of the implant closer to the loading point 23,24 or no difference in the loosening of the screws among different positions of implants ${ }^{12}$. However, according to Jacques et al. ${ }^{13}$, the contralateral screws presented greater tension, a result similar to that found in the present study, in which implant \#4 presented greater torque loss. Implants \# 2 and \#3 showed intermediate torque loss. In a previous study ${ }^{13}$ with five abutments, they found that \#1,\#4 and \# 5 abutments were subjected to a mixture of tensile and 
compressive forces, whereas \# 2 and \# 3 abutments were subject to high levels of stress. Other studies have found that all abutments received compressive or tensile loads, more or less intense, depending on their proximity to the force application site ${ }^{12,25}$. Greco et al. ${ }^{26}$ verified that the maximum stress values on the structure occurred when forces were applied in the distal portion. By visual inspection, deflection was verified in all the cantilever of the metal structures tested. Considering that it is a rigid and unique part under compressive force at one end, it is assumed that the other end receives tensile forces.

It is important to point out that in this study, the differential in the methodology was that the metal structures were obtained conventionally in the gypsum model, however, the tests were performed with the metal structures adapted to the polyurethane model that were obtained using the metal structures themselves, therefore, theoretically, providing an optimal adaptation, close to passivity. This fact may be related to obtaining different results from those of other works and in this way, suggesting the need for further research on the subject. The clinical implication of this work is that the loss of torque and subsequent loosening of the screw may go unnoticed by the professional and the patient, resulting in tensions on the other screws, structural damage, release of the prosthesis and damage to the bone tissue.

Thus, by this simulated protocol of a 3 month use of the prothesis, the loss of torque in all screws was verified, to a greater or lesser degree, in all bars. This signal that there is a need for periodical reassessment of the prosthesis protocol independent of extension of the cantilever.

\section{CONCLUSION}

Based on the results obtained in this study that simulated a 3 month masticatory activity, it can be concluded that all the screws presented torque loss, suggesting the need for periodical evaluation to prevent failures in the treatment.

\section{REFERENCES}

1. Misch CE. Dental implant prosthetics. 2nd ed. St. Louis: Elsevier; 2015. 993 p.

2. Koyano K, Esaki D. Occlusion on oral implants: current clinical guidelines. J Oral Rehabil. 2015 Feb;42(2):153-61. http://dx.doi.org/10.1111/joor.12239. PMid:25284468.

3. Adell R, Lekholm U, Rockler B, Brånemark PI. A 15-year study of osseointegrated implants in the treatment of the edentulous jaw. Int J Oral Surg. 1981 Dec;10(6):387-416. http://dx.doi.org/10.1016/S0300-9785(81)80077-4. PMid:6809663.

4. Drago C. Cantilever lengths and anterior-posterior spreads of interim, acrylic resin, full-arch screwretained prosthesis and their relationship to prosthetic complications. J Prosthodont. 2017 Aug;26(6):502-7. http://dx.doi.org/10.1111/jopr.12426. PMid:26848820.

5. Kreissl M, Gerds T, Muche R, Heydecke G, Strub JR. Technical complications of implant-supported fixed partial dentures in partially edentulous cases after an anverage observation period of 5 years. Clin Oral Implants Res. 2007 Dec;18(6):720-6. http://dx.doi.org/10.1111/j.1600-0501.2007.01414.x. PMid:17888017.

6. Pjetursson BE, Zarauz C, Strasding M, Sailer I, Zwahlen M, Zembic A. A systematic review of the influence of the implant-abutment connection on the clinical outcomes of ceramic and metal implant abutments supporting fixed implant reconstructions. Clin Oral Implants Res. 2018 Oct;29(Suppl 18):160-83. http://dx.doi.org/10.1111/clr.13362. PMid:30306682.

7. Bacchi A, Consani RLX, Mesquita MF, Santos MBF. Stress distribution in fixed-partial prosthesis and peri-implant bone tissue with diferente framework materials and vertical misfit levels: a three- 
dimensional finite element analysis. J Oral Sci. 2013;55(3):239-44.

http://dx.doi.org/10.2334/josnusd.55.239. PMid:24042591.

8. Dixon DL, Breeding L, Sadler JP, Mckay ML. Comparison of screw loosening, rotation, and deflection among three implant design. J Prosthet Dent. 1995 Sep;74(3):270-8. http://dx.doi.org/10.1016/S0022-3913(05)80134-9. PMid:7473281.

9. Bhering CLB, Takahashi JMFK, Luthi LF, Henriques GEP, Consani RLX, Mesquita MF. Influence of the casting technique and dynamics loading on screw detorque and misfit of single unit implant-supported prostheses. Acta Odontol Scand. 2013 May-Jul;71(3-4):404-9. http://dx.doi.org/10.3109/00016357.2012.690528. PMid:22607236.

10. Nissan J, Gross M, Shifman A, Assif D. Stress levels for well-fitting implant superstructures as a function of tightening force levels, tightening sequence, and different operators. J Prosthet Dent. 2001 Jul;86(1):20-3. http://dx.doi.org/10.1067/mpr.2001.115182. PMid:11458260.

11. Farina AP, Spazzin AO, Consani RLX, Mesquita MF. Screw Joint stability after the application of retorque in implant-supported dentures under simulated masticatory conditions. J Prosthet Dent. 2014 Jun;111(6):499-504. http://dx.doi.org/10.1016/j.prosdent.2013.07.024. PMid:24423456.

12. Suedam V, Souza EA, Moura MS, Jacques LB, Rubo JH. Effect of abutment's height and framework alloy on the load distribution of mandibular cantilevered implant-supported prosthesis. Clin Oral Implants Res. 2009 Feb;20(2):196-200. http://dx.doi.org/10.1111/j.1600-0501.2008.01609.x. PMid:19191796.

13. Jacques LB, Moura MS, Suedam V, Souza EAC, Rubo JH. Effect of cantilever length and framework alloy on the strss distribuition of mandibular-cantilevered implant-supported prostheses. Clin Oral Implants Res. 2009 jul;20(7):737-41. http://dx.doi.org/10.1111/j.1600-0501.2009.01712.x. PMid:19489929.

14. Siamos G, Winkler S, Boberick K. The relationship between implant preload and screw loosening on implant-supported prostheses. J Oral Implantol. 2002;28(2):67-73. http://dx.doi.org/10.1563/15481336(2002)028<0067:TRBIPA>2.3.CO;2. PMid:12498448.

15. Walter L, Greenstein G. Utility of measuring anterior-posterior spread to determine distal cantilever length off a fixed implant-supported full-arch prosthesis: a review of the literature. J Am Dent Assoc. 2020;151(10):790-5. http://dx.doi.org/10.1016/j.adaj.2020.06.016. PMid:32979958.

16. Medeiros RA, Goiato MC, Pesqueira AA, Vechiato AJ Fo, Bonatto LD, Santos DM. Stress distribution in an implant-supported mandibular complete denture using different cantilever lengths and occlusal coating materials. Implant Dent. 2017 Feb;26(1):106-11. http://dx.doi.org/10.1097/ID.0000000000000534. PMid:28060024.

17. Cid RMO, Stanley K, Cordero EB, Benfatti CAM, Bianchini MA. Influence of cantilever length and type of arch antagonist on bone loss in total implant-supported prosthesis. Acta Odontol Latinoam. 2014;27(3):131-6. http://dx.doi.org/10.1590/S1852-48342014000300006. PMid:25560692.

18. Hanif A, Qureshi S, Sheikh Z, Rashid H. Complications in implant dentistry. Eur J Dent. 2017 JanMar;11(1):135-40. http://dx.doi.org/10.4103/ejd.ejd_340_16. PMid:28435381.

19. Pereira J, Morsch CS, Henriques B, Nascimento RM, Benfatti CA, Silva FS, et al. Removal torque and biofilm accumulation at two dental implant-abutment joints after fatigue. Int J Oral Maxillofac Implants. 2016 Jul-Aug;31(4):813-9. http://dx.doi.org/10.11607/jomi.4173. PMid:27447147.

20. Cantwell A, Hobkirk JA. Preload loss in gold prosthesis-retaining screws as a function of time. Int J Oral Maxillofac Implants. 2004 Jan-Feb;19(1):124-32. PMid:14982365.

21. Breeding LC, Dixon DL, Nelson EW, Tietge ID. Torque required to loosen single- tooth implant abutment screws before and after simulated function. Int J Prosthodont. 1993 Sep-0ct;6(5):435-9. PMid:8297452.

22. Jemt T. In vivo measurements of precision of fit involving implant-supported prosthesis in the edentulous jaw. Int J Oral Maxillofac Implants. 1996 Mar-Apr;11(2):151-8. PMid:8666445. 
23. Calandriello R, Tomatis M. Simpliflied treatment of the atrophic posterior maxilla via immediate/early function tilted implants: a prospective 1-year clinical study. Clin Implant Dent Relat Res. 2005;7(Suppl 1):S1-12. http://dx.doi.org/10.1111/j.1708-8208.2005.tb00069.x. PMid:16137082.

24. Rodriguez AM, Aquilino SA, Lund PS. Cantilever and implant biomechanics: a review of the literature part 2. J Prosthodont. 1994 Jun;3(2):114-8. http://dx.doi.org/10.1111/j.1532-849X.1994.tb00138.x. PMid:9227107.

25. Rubo JH, Souza EAC. Finite element analysis of stress in bone adjacent to dental implants. J Oral Implantol. 2008;34(5):248-55. http://dx.doi.org/10.1563/1548-1336(2008)34[249:FEAOSI]2.0.CO;2. PMid:19170290.

26. Greco GD, Jansen WC, Landre Júnior J, Seraidarian PI. Biomechanical analysis of the stresses generated by different disocclusion patterns in an implant-supported mandibular complete denture. J Appl Oral Sci. 2009 Sep-Oct;17(5):515-20. http://dx.doi.org/10.1590/S1678-77572009000500029. PMid:19936535.

\section{CONFLICTS OF INTERESTS}

The authors declare no conflicts of interest.

\section{${ }^{*}$ CORRESPONDING AUTHOR}

Wilson Matsumoto, USP - Universidade de São Paulo, Faculdade de Odontologia de Ribeirão Preto, Departamento de Materiais Odontológicos e Prótese, Av. Do Café, s/n, Monte Alegre, 14020-590 Ribeirão Preto - SP, Brasil, e-mail: wmatsumoto@forp.usp.br

Received: July 2, 2020

Accepted: December 15, 2020 